\title{
Morphological and molecular characterization of Posthodiplostomum sp. (Digenea: Diplostomidae) metacercaria in the muscles of snakeheads (Channa punctata) from Manipur, India
}

\author{
V. D. ATHOKPAM, V. TANDON \\ Department of Zoology, North-Eastern Hill University, Shillong 793022, Meghalaya, India, \\ Email: voleentina.athokpam@gmail.com,tandonveena@gmail.com
}

\begin{abstract}
Summary
The spotted snakehead, Channa punctata Bloch, 1793, is a locally important fish species commonly consumed by the natives in the state of Manipur, Northeast India. The fish host C. punctata from Lamphel area revealed a diplostomid metacercarial infection. Morphologically, the recovered metacercaria was identified as a species of Posthodiplostomum Dubois, 1936. Molecular characterization using the ribosomal RNA genes (rDNA 18S, ITS2 and $28 \mathrm{~S}$ regions) and the mitochondrial $\mathrm{CO} 1$ region supplements the identification. Molecular analysis revealed the metacercaria to be closely related to Posthodiplostomum sp. Japan isolate, with sequence similarity variation from 97.5 - $99.7 \%$ while considering for the three rDNA markers. The secondary structure of the ITS 2 region further corroborated these results; the typical four-helix model, when compared to the taxon from Japan, showed differences only in twelve bases (with seven transitions and five transversions). In phylogenetic analysis also, the metacercaria claded with the genus Posthodiplostomum, coming closer to the Japanese isolate, thus supplementing the morphological identification of the metacercaria.
\end{abstract}

Keywords: fish; Channa punctata; metacercaria; Posthodiplostomum sp.; morphology; morphometry; rDNA; mtCO1

\section{Introduction}

Species of Posthodiplostomum Dubois, 1936, a genus of digenean flukes in the family Diplostomidae has been frequently reported in Cypriniformes (Ishii, 1951; Nagasawa et al., 1989; Zrnčić et al., 2009), Channiformes (Nguyen et al., 2012) and Perciformes (Karimian et al., 2013). There are about 30 species of Posthodiplostomum reported from bird hosts (Yamaguti, 1971; Sonin, 1986), which utilize a wide range of cypriniform fishes as their second intermediate host; the family Cyprinidae in parti- cular constitutes the largest group of hosts being affected (Lucky, 1970; Chubb, 1977; Jalali, 1998; Rolbiecki, 2004; Ondračková et al., 2004a; Vytautas \& Èeslovas, 2009; Karimian et al., 2013). Of these species, the metacercariae of $P$. cuticola are responsible for causing 'Black spot' disease in the fish host (Dönges, 1964; Schäpperclaus, 1990; Ondračková et al., 2004b; Karimian et al., 2013) and those of $P$. brevicaudatum encysting in the eye lens cause ocular parasitosis (Dönges, 1969; Stanevičiūtè et al., 1998). However, another species, P. minimum, is responsible for causing 'white grub' in fishes (Colley \& Olson, 1963; Lewis \& Nickum, 1964; Avault \& Smitherman, 1965; Lane \& Morris, 2000). There is only one report of Posthodiplostomum metacercarial infection occurring in the channid fish (Nguyen et al., 2012). In fish intermediate hosts, the parasite occurs encysted in the skin, fins, cornea and superficial muscles as the etiological agent of blackspot disease (Kurochkin \& Biserova, 1996; Shukhgalter \& Chukalova, 2002; Ondračková et al., 2002, 2004b). Piscivorous birds, mainly herons (Ardeidae), are definitive host for the parasite in Eurasia (Skrjabin, 1964; Yamaguti, 1971).

Molecular characterization of larval and adult forms of various diplostomid taxa utilizing data from rDNA markers has proven to be useful in supplementing their morphology-based identification (Galazzo et al., 2002; Niewiadomska \& Laskowski, 2002; Criscione et al., 2005; Nguyen et al., 2012; Zhao et al., 2012). The mitochondrial cytochrome oxidase 1 (mtCO1) gene has also been largely utilized as a tool in molecular discrimination of digenean species (Nolan \& Cribb, 2005; Olson \& Tkach, 2005).

In a pilot study carried out to evaluate the status of metacercarial infections in freshwater fishes in Manipur, the snakehead fish, Channa punctata Bloch, 1793, was frequently found harbouring a diplostomid (Posthodiplostomum sp.) infection in the skin (Athokpam \& Tandon, 2013). As a sequel to the same, the present study was taken 
up to morphologically and molecularly characterize this metacercaria to determine its systematic position. To achieve this goal, rDNA ITS2, $18 \mathrm{~S}$ and $28 \mathrm{~S}$ and $\mathrm{mtCO} 1$ gene regions were used as molecular markers.

\section{Material and methods}

\section{Study area and morphology study}

Live C. punctata were collected from the focal area of Posthodiplostomum infection, i.e., Lamphel (Imphal West District, Manipur). The host muscle, skin, fins, gills, oral cavity and eyes were examined under a stereomicroscope to detect any infection with metacercariae.

For morphological identification, the metacercarial cysts were excysted artificially by providing a gentle mechanical pressure and flattened between a glass slide and a cover glass. They were then fixed in $70 \%$ ethyl alcohol, processed for whole mount preparation and stained with acetocarmine stain following the standard protocol. Observations were made using Leitz Ortholux-2 research microscope and line drawing sketched using camera lucida. Morphometric measurements (in millimetre) of the cyst and excysted metacercaria were taken with the help of ocular micrometer.

\section{Molecular study \\ DNA isolation, amplification and sequencing}

DNA was extracted from the excysted unflattened metacercariae separated from a single fish host, fixed in $70 \%$ ethyl alcohol using QIAamp DNA Mini Kit (50) according to the manufacturer's instructions.

For PCR-amplification we used three rDNA marker gene regions: $18 \mathrm{~S}, 28 \mathrm{~S}$ and internal transcribed spacer 2 (ITS2) and the mitochondrial cytochrome oxidase subunit 1 (CO1) region. Primers used for the respective gene region are detailed as follows:

ITS2: 3S (Forward)/ A28 (Reverse) (Bowles et al., 1995)

18S: EukA (Forward)/ EukB (Reverse) (Diez et al., 2001)

28S: dig12 (Forward)/ 1500R (Reverse) (Tkach et al., 2000) mtCO1: JB3 (Forward)/ JB4.5 (Reverse) (Bowles et al., 1993).

The thermal gradient of these marker regions started with an initial denaturation at $94{ }^{\circ} \mathrm{C}(5 \mathrm{~min})$, annealing - for $18 \mathrm{~S}$ at $58{ }^{\circ} \mathrm{C}(1.10 \mathrm{~min}), 28 \mathrm{~S}$ at $57^{\circ} \mathrm{C}(1 \mathrm{~min})$, ITS2 at $57^{\circ} \mathrm{C}$ $(1.10 \mathrm{~min})$ and $\mathrm{CO} 1$ at $56^{\circ} \mathrm{C}(1.10 \mathrm{~min})$, and final extension at $72^{\circ} \mathrm{C}(10 \mathrm{~min})$. The amplified PCR products were separated by electrophoresis through $1.6 \%(\mathrm{w} / \mathrm{v})$ agarose gels in TAE buffer, stained with ethidium bromide, transilluminated under ultraviolet light, and then photographed. PCR products were purified using Genei Quick PCR purification kit for DNA sequencing, and sequenced in both directions using PCR primer sets utilizing Macrogen sequencing service, Korea.

\section{Sequence analysis}

Similarity search was carried out using Basic Local Alignment Search Tool (BLAST) available at http://www.ncbi.nlm.nih.go v/blast. Since the full length of the $18 \mathrm{~S}$ and $28 \mathrm{~S}$ rRNA could not be retrieved from one direction sequencing, the contigs were created by assembling the forward and reversed sequences of the genes using DNA Baser v3.5.3 (http://www.dnabaser.com/). Multiple sequence alignments were done for each of the amplified markers from the studied metacercaria, with related sequences from superfamily Diplostomoidea retrieved from GenBank (Table 2), using ClustalW of Bioedit software (http://www. ebi.ac.uk/clustalw). For sequence identities Bioedit software version 7.0.9.0 (Hall, 1999) was used.

\section{Phylogenetic analysis}

The rDNA ITS2 sequences were used for phylogenetic studies, using various bioinformatic tools. The ITS2 rDNA plus the flanking $5.8 \mathrm{~S}$ and $28 \mathrm{~S}$ sequences were first annotated using the hidden Markov models (HMM)-based annotation to retrieve the exact sequence of the region (Keller et al., 2009) available at http://its2.bioapps.biozentrum.uniwuerzburg.de/. The output fasta format files from Bioedit were then entered into MEGA5 for phylogenetic tree construction using the distance-based Neighbour Joining (NJ) method and character-based Maximum Parsimony (MP). Bayesian Inference (BI) analysis was also done by aligning the sequences using Clustal X 2.0.7; the NEXUS file format was generated and alignments were imported to Mr.Bayes v3.1.2 programme (Huelsenbeck \& Ronquist, 2001), using GTR $+\mathrm{I}+\mathrm{G}$ model. Markov Chain Monte Carlo (MCMC) chains were generated following Shylla et al. (2011) with some modifications: ngen $=250000$ (ITS2); 100000 (18S); 200000 (28S); 'sump burnin' = 6250 (ITS2); 2500 (18S); 5000 (28S) and 'sumt burnin' = 6250 (ITS2); 2500 (18S); 5000 (28S). In addition to the sequence data set used in the analysis, Clinostomum sequence was included as the outgroup taxon. Phylogenetic accuracy was done by bootstrapping the constructed trees.

\section{Predicted ITS2 RNA secondary structures}

The ITS2 secondary structure was used as a supplementary tool to phylogenetic analysis. Secondary structure of the annotated ITS2 sequence was reconstructed with MFOLD software version 3.2, using free energy folding algorithms (Zuker, 2003) and the structure with lowest free energy was taken for analysis. The consensus secondary structure was generated with Posthodiplostomum sp. Japan isolate (accession number: AB693170.1) using 4Sale (Seibel et al., 2006).

\section{Results}

\section{Morphology and morphometry}

Based on its morphological attributes, the metacercaria recovered from the infected host's muscle was identified as belonging to the genus Posthodiplostomum Dubois, 1936 (Family: Diplostomidae Poirier, 1886) and is describe as follows.

Description (based on 10 specimens). Metacercarial cyst oval or round in shape, surrounded by a single layered cyst 


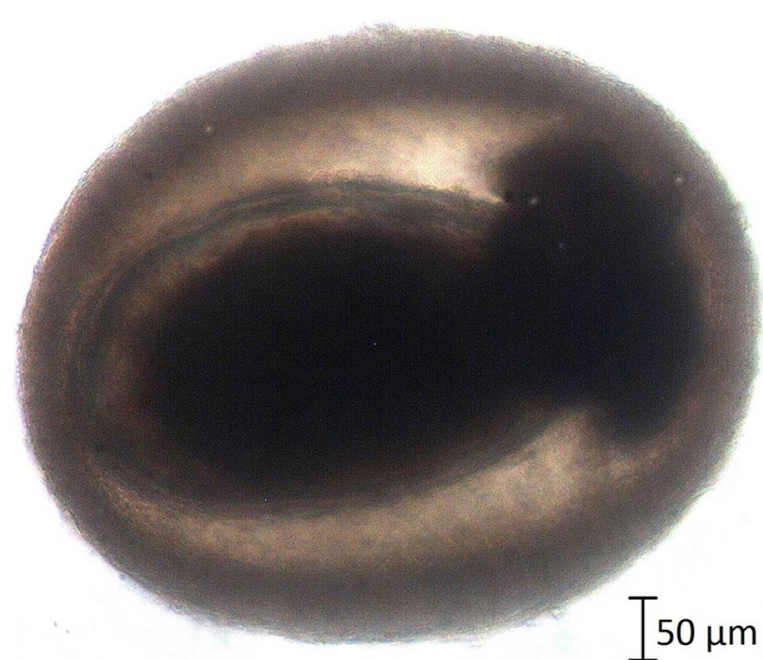

Fig. 1. Encysted metacercaria recovered from the muscle tissue of C. punctata

wall, $0.64-0.67(0.65 \pm 0.01) \mathrm{mm}$ by $0.53-0.55(0.51 \pm$ $0.06) \mathrm{mm}$ in size (Fig. 1). Excysted metacercaria with distinctly bipartite body, typically 'Neascus' type. Forebody: somewhat foliaceous or lanceolate; pseudosuckers absent; oral and ventral suckers feebly developed, small in size; pharynx small, conspicuous; intestinal caeca not prominent; trybocytic organ disc-like or almond-shaped, with cavity opening via median slit, holdfast gland present; reserve bladder composed of 3 longitudinal canals (one median, two lateral) ramifying and forming net in forebody, excretory bodies free in canal ramifications. Hindbody: somewhat oval, stump-like, lodging primordia of gonads that occupy greater space. Testes two, one behind other in median field; anterior testis smaller, oval, laterally or submedially placed; posterior testis larger in size, transversely elongate. Ovary small, rounded, submedian or lateral or diagonal to anterior testis. Copulatory bursa evertible, with terminal opening (Fig. 2).

Morphometric measurements of the particular body parts of the mounted metacercaria are given in Table 1.

\section{Molecular study}

Molecular analysis and characterization

The select marker regions as mentioned above were amplified successfully; the obtained sequences were deposited in GenBank and their accession numbers obtained [KF738447 (ITS2), KF738450 (28S), KF738455 (18S) and KF738453 (CO1)]. The amplicon size of ITS2, 28S, 18S and $\mathrm{CO} 1$ was $441 \mathrm{bp}, 1117 \mathrm{bp}, 1877 \mathrm{bp}$ and $366 \mathrm{bp}$ in length, respectively. The sequences generated from the present study were aligned with those of strigeidae and

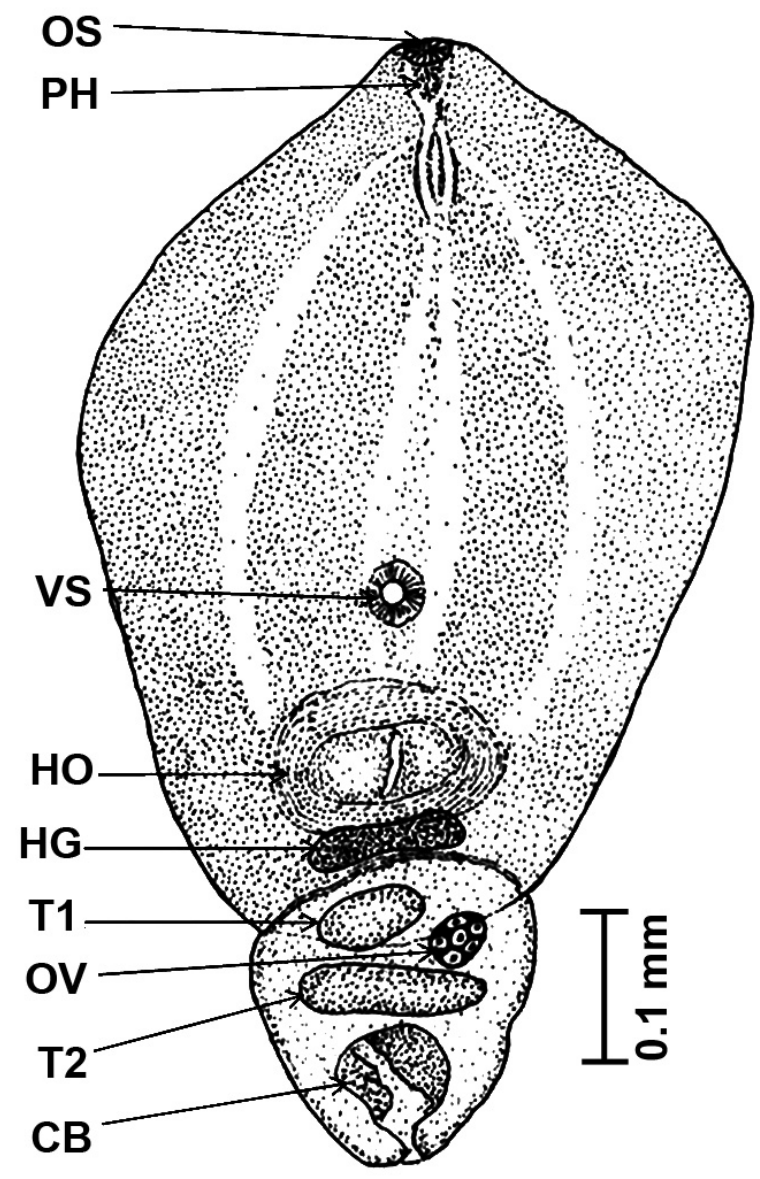

Fig. 2. Excysted metacercaria-line drawing (camera lucida), CB - copulatory bursa, HG - holdfast gland, HO - holdfast organ, OS - oral sucker, OV - ovary, PH - pharynx, T1 - anterior testis, T2 - posterior testis, VS - ventral sucker 
Table 1. Morphometric measurements (in $\mathrm{mm}$ ) of the excysted metacercaria of Posthodiplostomum sp.

\begin{tabular}{|c|c|c|c|}
\hline Characters & Range (mm) & Mean & \pm SD \\
\hline Body length & $0.504-0.675$ & 0.635 & \pm 0.069 \\
\hline \multicolumn{4}{|l|}{ Forebody } \\
\hline Length & $0.396-0.495$ & 0.445 & \pm 0.074 \\
\hline Width & $0.315-0.567$ & 0.444 & \pm 0.085 \\
\hline \multicolumn{4}{|l|}{ Hindbody } \\
\hline Length & $0.099-0.18$ & 0.150 & \pm 0.029 \\
\hline Width & $0.135-0.198$ & 0.158 & \pm 0.035 \\
\hline \multicolumn{4}{|l|}{ Oral Sucker } \\
\hline Length & $0.014-0.030$ & 0.023 & \pm 0.007 \\
\hline Width & $0.020-0.032$ & 0.027 & \pm 0.005 \\
\hline \multicolumn{4}{|l|}{ Ventral sucker } \\
\hline Length & $0.048-0.05$ & 0.049 & \pm 0.001 \\
\hline Width & $0.048-0.05$ & 0.049 & \pm 0.001 \\
\hline \multicolumn{4}{|l|}{ Pharynx } \\
\hline Length & $0.030-0.036$ & 0.033 & \pm 0.004 \\
\hline Width & 0.016 & 0.016 & 0 \\
\hline \multicolumn{4}{|l|}{ Holdfast gland } \\
\hline Length & $0.012-0.018$ & 0.016 & \pm 0.003 \\
\hline Width & $0.060-0.075$ & 0.069 & \pm 0.007 \\
\hline \multicolumn{4}{|l|}{ Holdfast: } \\
\hline Length & $0.060-0.075$ & 0.064 & \pm 0.007 \\
\hline Width & $0.090-0.105$ & 0.099 & \pm 0.008 \\
\hline \multicolumn{4}{|l|}{ Anterior Testis } \\
\hline Length & $0.021-0.210$ & 0.087 & \pm 0.107 \\
\hline Width & $0.042-0.054$ & 0.047 & \pm 0.005 \\
\hline \multicolumn{4}{|l|}{ Posterior Testis } \\
\hline Length & $0.018-0.030$ & 0.022 & \pm 0.007 \\
\hline Width & $0.078-0.090$ & 0.084 & \pm 0.006 \\
\hline \multicolumn{4}{|l|}{ Ovary } \\
\hline Length & $0.018-0.021$ & 0.019 & \pm 0.001 \\
\hline Width & $0.027-0.030$ & 0.028 & \pm 0.001 \\
\hline \multicolumn{4}{|l|}{ Bursa } \\
\hline Length & $0.060-0.660$ & 0.063 & \pm 0.003 \\
\hline Width & $0.045-0.057$ & 0.052 & \pm 0.005 \\
\hline
\end{tabular}

diplostomid taxa retrieved from the GenBank (Table 2). The metacercaria under the present study stands very close to Posthodiplostomum sp. Japan isolate with sequence identities of $97.5 \%$ (ITS2), $99.7 \%(18 \mathrm{~S})$ and $97.5 \%$ $(28 \mathrm{~S})$, showing very low variation $(0.3-2.5 \%)$ between the two (Tables $3-5$ ).
Phylogenetic study

The phylogenetic trees constructed for the three rDNA genes using MP, NJ and BI methods showed almost the same topology of taxa; therefore, to avoid any repetition only the BI tree is shown herein (Fig. 3a-c). All trees revealed that the present metacercaria clades with Posthodiplostomum sp. Japan isolate. 
Table 2. Diplostomidae and Strigeidae species sequences of rDNA used in the analysis with their respective GenBank accession numbers

\begin{tabular}{|c|c|c|c|c|c|c|}
\hline $\begin{array}{l}\text { Sr. } \\
\text { No. }\end{array}$ & Name of species & Family & Host Species & Locality & $\begin{array}{l}\text { Marker } \\
\text { Region }\end{array}$ & $\begin{array}{l}\text { Accession } \\
\text { no. }\end{array}$ \\
\hline 1. & Alaria alata & Diplostomidae & - & France & ITS2 & JF340223.1 \\
\hline 2. & A. alata & “ & $\begin{array}{l}\text { Nyctereutes } \\
\text { procyonoides }\end{array}$ & Ukraine & $\begin{array}{l}\text { 18S rDNA } \\
28 \mathrm{~S} \text { rDNA }\end{array}$ & $\begin{array}{l}\text { AY222091.1 } \\
\text { AF184263.1 }\end{array}$ \\
\hline 3. & A. alata & “ & Sus scrofa & Italy & $\mathrm{CO} 1$ & HM022223.1 \\
\hline \multirow[t]{2}{*}{4.} & \multirow[t]{2}{*}{ A. taxideae } & \multirow[t]{2}{*}{ “ } & - & \multirow[t]{2}{*}{ USA } & ITS2 & JF820609.1 \\
\hline & & & Lithobates sylvaticus & & $28 \mathrm{~S}$ rDNA & JF820607.1 \\
\hline \multirow[t]{3}{*}{5.} & \multirow[t]{3}{*}{ Bolbophorus sp. } & \multirow[t]{3}{*}{ “ } & \multirow[t]{3}{*}{-} & \multirow[t]{3}{*}{ USA } & ITS2 & AF470611.1 \\
\hline & & & & & $18 \mathrm{~S}$ rDNA & AF490575.1 \\
\hline & & & & & $\mathrm{CO} 1$ & AF470615.1 \\
\hline \multirow[t]{2}{*}{6.} & \multirow[t]{2}{*}{ B. confuses } & \multirow[t]{2}{*}{ “ } & \multirow[t]{2}{*}{-} & \multirow[t]{2}{*}{ Israel } & ITS2 & AY242851.1 \\
\hline & & & & & $18 \mathrm{~S}$ rDNA & AY242851.1 \\
\hline \multirow[t]{2}{*}{7.} & \multirow[t]{2}{*}{ B. damnificus } & \multirow[t]{2}{*}{ “ } & Pelican & \multirow[t]{2}{*}{ USA } & $18 \mathrm{~S}$ rDNA & AF490574.1 \\
\hline & & & - & & $\mathrm{CO} 1$ & AF470609.1 \\
\hline 8. & B. levantinus & “ & Night heron & USA & 18S rDNA & AF490576.1 \\
\hline 9. & Diplostomum sp. & “ & Lithobates sylvaticus & Canada & ITS2 & GQ292510.1 \\
\hline 10. & Diplostomum sp. & “ & Lymnaea stagnalis & USA & 28S rDNA & JX262945.1 \\
\hline 11. & D. compactum & “ & - & USA & $18 \mathrm{~S}$ rDNA & AY245764.1 \\
\hline \multirow[t]{2}{*}{12.} & \multirow[t]{2}{*}{ D. phoxini } & \multirow[t]{2}{*}{ “ } & \multirow[t]{2}{*}{ Phoxinus phoxinus } & \multirow[t]{2}{*}{ UK } & $18 \mathrm{~S}$ rDNA & AY222090.1 \\
\hline & & & & & $28 \mathrm{~S}$ rDNA & AY222173.1 \\
\hline 13. & D. pseudospathaceum & “ & Larus cachinnans & $\begin{array}{l}\text { Czech } \\
\text { Republic }\end{array}$ & ITS2 & JX986854.1 \\
\hline 14. & D. spathaceum indistinctum & “ & - & USA & $18 \mathrm{~S}$ rDNA & AY245761.1 \\
\hline 15. & Neodiplostomum seoulense & “ & - & Korea & $\mathrm{CO} 1$ & AF096233.2 \\
\hline 16. & Ornithodiplostomum sp. & “ & Percina caprodes & Canada & ITS2 & HМ064934.1 \\
\hline \multirow[t]{3}{*}{17.} & Posthodiplostomum sp. & “ & Channa argus & Japan & ITS2 & AB693170.1 \\
\hline & & & & & $18 \mathrm{~S}$ rDNA & AB693170.1 \\
\hline & & & & & 28S rDNA & AB693170.1 \\
\hline 18. & Posthodiplostomum sp. & “ & Lepomis gibbosus & Canada & ITS2 & HМ064957.1 \\
\hline 19. & P. minimum & “ & - & USA & 18S rDNA & AY245767.1 \\
\hline 20. & Tylodelphys scheuringi & “ & - & Canada & ITS2 & FJ469596.1 \\
\hline 21. & T. mashonensis & “ & - & $\begin{array}{l}\text { Czech } \\
\text { Republic }\end{array}$ & ITS2 & KC685362.1 \\
\hline 22. & Apharyngostrigea pipientis & Strigeidae & Nycticorax nycticorax & USA & $28 \mathrm{~S}$ rDNA & JF820597.1 \\
\hline 23. & $\begin{array}{l}\text { Cardiocephaloides } \\
\text { longicollis }\end{array}$ & “ & Larus ridibundus & Ukraine & 28S rDNA & AY222171.1 \\
\hline 24. & Strigeidae gen. & “ & - & Canada & ITS2 & HМ064970.1 \\
\hline 25. & Strigeidae sp. & & - & Israel & ITS2 & AY245711.1 \\
\hline 26. & Strigeidae sp. & & Cominella glandiformis & New Zealand & $\mathrm{CO} 1$ & FJ765509.1 \\
\hline 27. & Strigeidida sp. & & - & USA & 18S rDNA & EU371593.1 \\
\hline
\end{tabular}


a.

gb|GQ339114.1|Clinostomum sp.

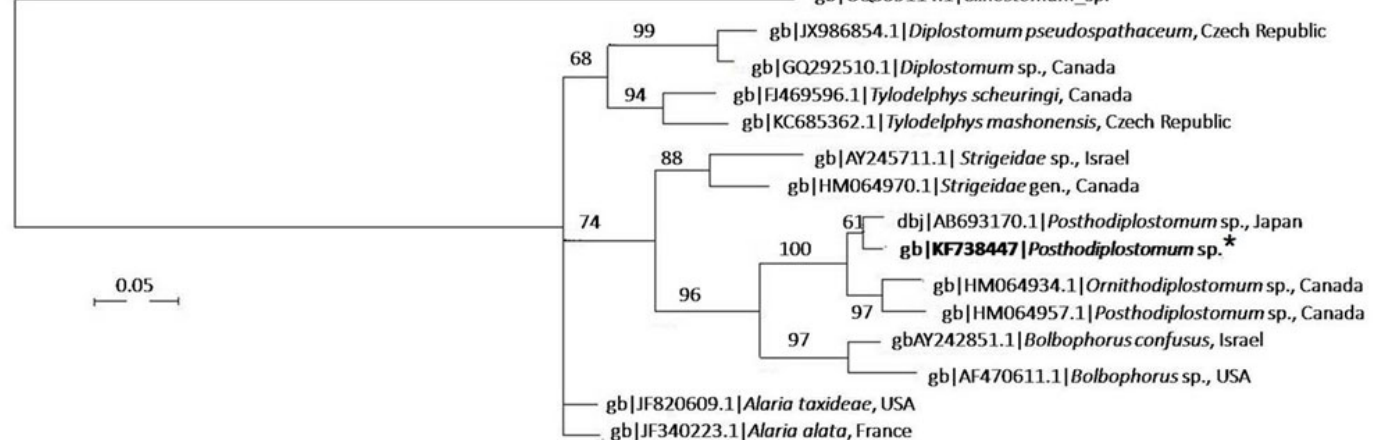

b.

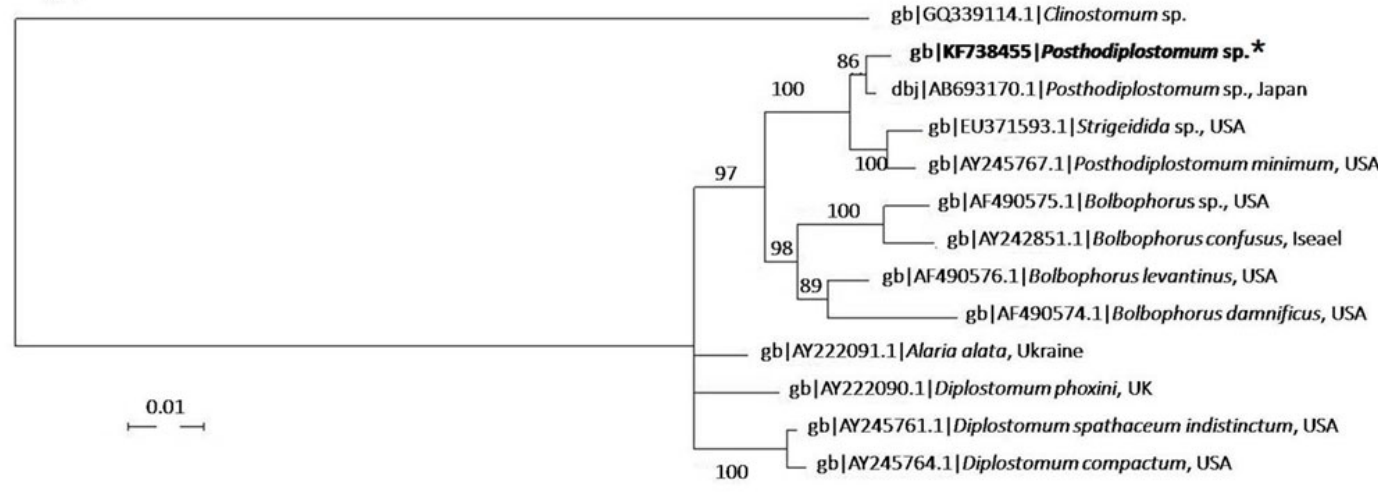

C.

gb|GQ339114.1|Clinostomum sp.
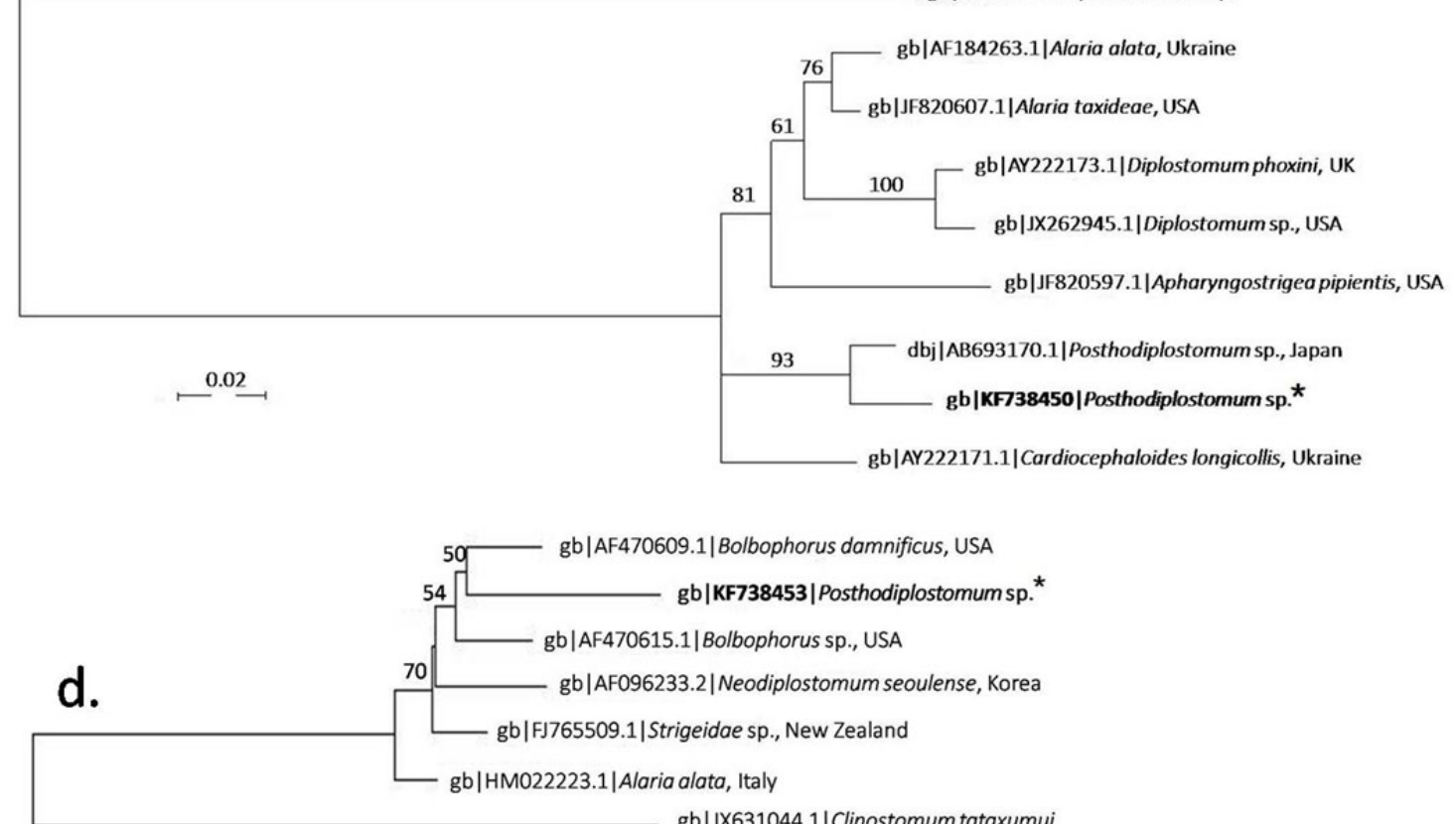

$\mathrm{gb} \mid \mathrm{JX631044.1|Clinostomum} \mathrm{tataxumui}$

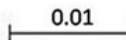

Fig. 3. Phylogenetic trees depicting relationships of the diplostomid and strigeid taxa inferred from rDNA and mtCO1 markers data. a - c. Bayesian Inference (BI) tree: (a) ITS2, (b) 18S, (c) 28S. d. NJ tree: mtCO1.

('*'- query sequence generated in the study) 


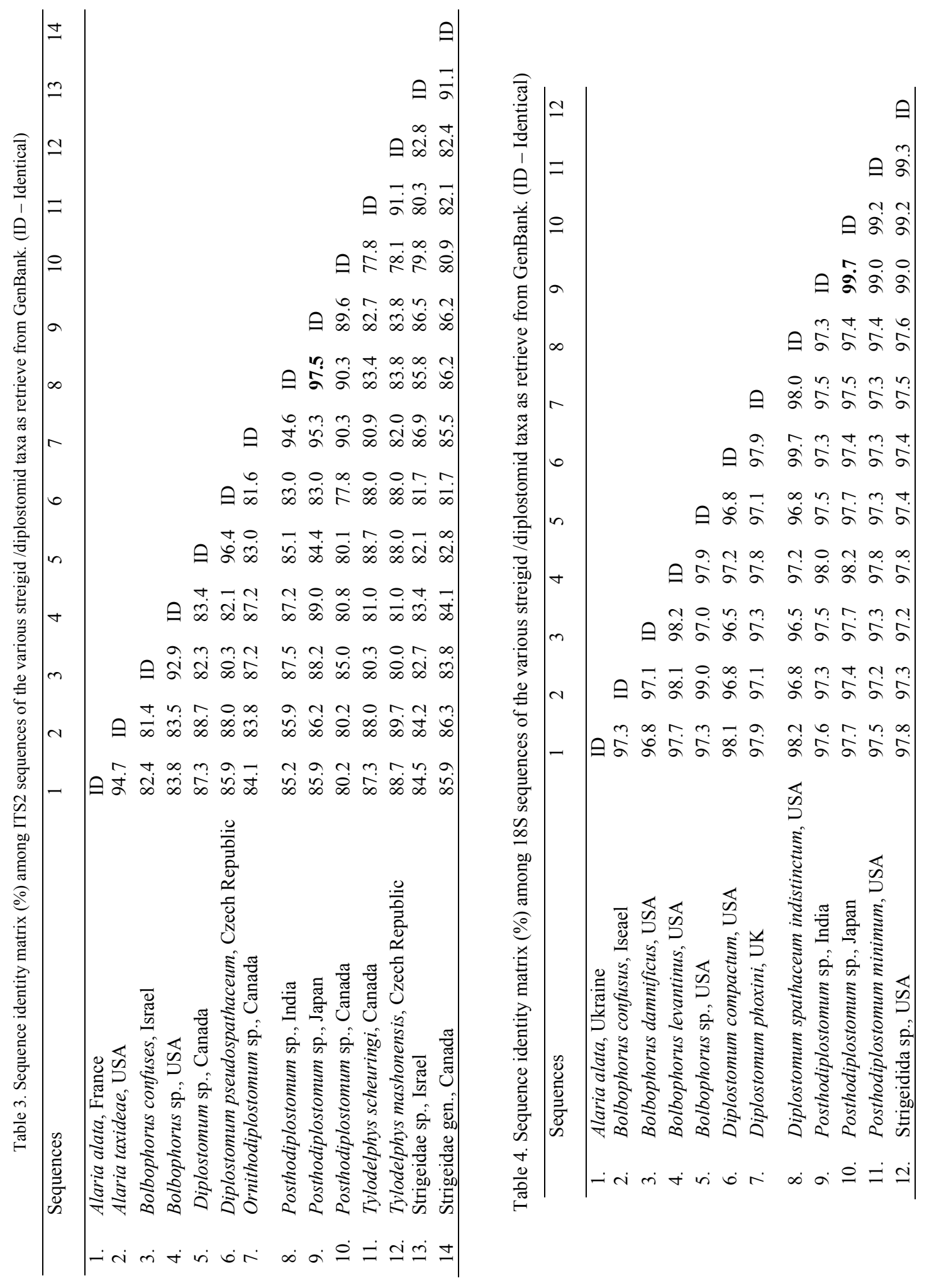


Table 5. Sequence identity matrix (\%) among $28 \mathrm{~S}$ sequences of the various streigid /diplostomid taxa as retrieve from GenBank. (ID - Identical)

\begin{tabular}{llllllllll}
\hline & Sequences & 1 & 2 & 3 & 4 & 5 & 6 & 7 & 8 \\
\hline 1. & Alaria alata, Ukraine & ID & & & & & & & \\
2. Alaria taxideae, USA & 98.5 & ID & & & & & & \\
3. Diplostomum phoxini, UK & 96.0 & 96.0 & ID & & & & & \\
4. Diplostomum sp., USA & 95.7 & 95.7 & 98.7 & ID & & & & \\
5. Posthodiplostomum sp., India & 93.0 & 93.2 & 92.1 & 91.9 & ID & & & \\
6. Posthodiplostomum sp., Japan & 93.6 & 94.1 & 92.7 & 92.5 & $\mathbf{9 7 . 5}$ & ID & & \\
7. Apharyngostrigea pipientis, USA & 94.2 & 94.7 & 93.5 & 93.1 & 92.5 & 92.5 & ID & \\
& & & & & & & & & \\
8. Cardiocephaloides longicollis, & 94.7 & 95.2 & 94.5 & 94.0 & 93.0 & 93.2 & 93.0 & ID \\
& Ukraine & & & & & & & & \\
\hline
\end{tabular}

For mtCO1 region, only the NJ tree could be constructed using the sequence data pertaining to Diplostomidae and Strigeidae taxa, available in the public domain (Table 2, Fig. 3d). The CO1 tree showed that the query sequence claded with Bolbophorus damnificus (family Diplostomidae), though with a low bootstrap value. However, at the family level a higher bootstrap value $(70 \%)$ with Neodiplostomum seoulense was revealed. In all trees Clinostomum sp., the outgroup, formed a distinct clade.
ITS2 RNA secondary structures analysis

The secondary structure of the annotated ITS2 sequence having a length of 292 bp was analyzed. It displayed the typical four-helix model: helix I and IV being very short, helix II having three U-U mismatches, and helix III being the longest with two UGGG motifs (Fig. 4a).

The consensus secondary structure constructed using ITS2 sequences of Posthodiplostomum sp. under study and the Japan isolate (Fig. 4b) also revealed a typical four-helix

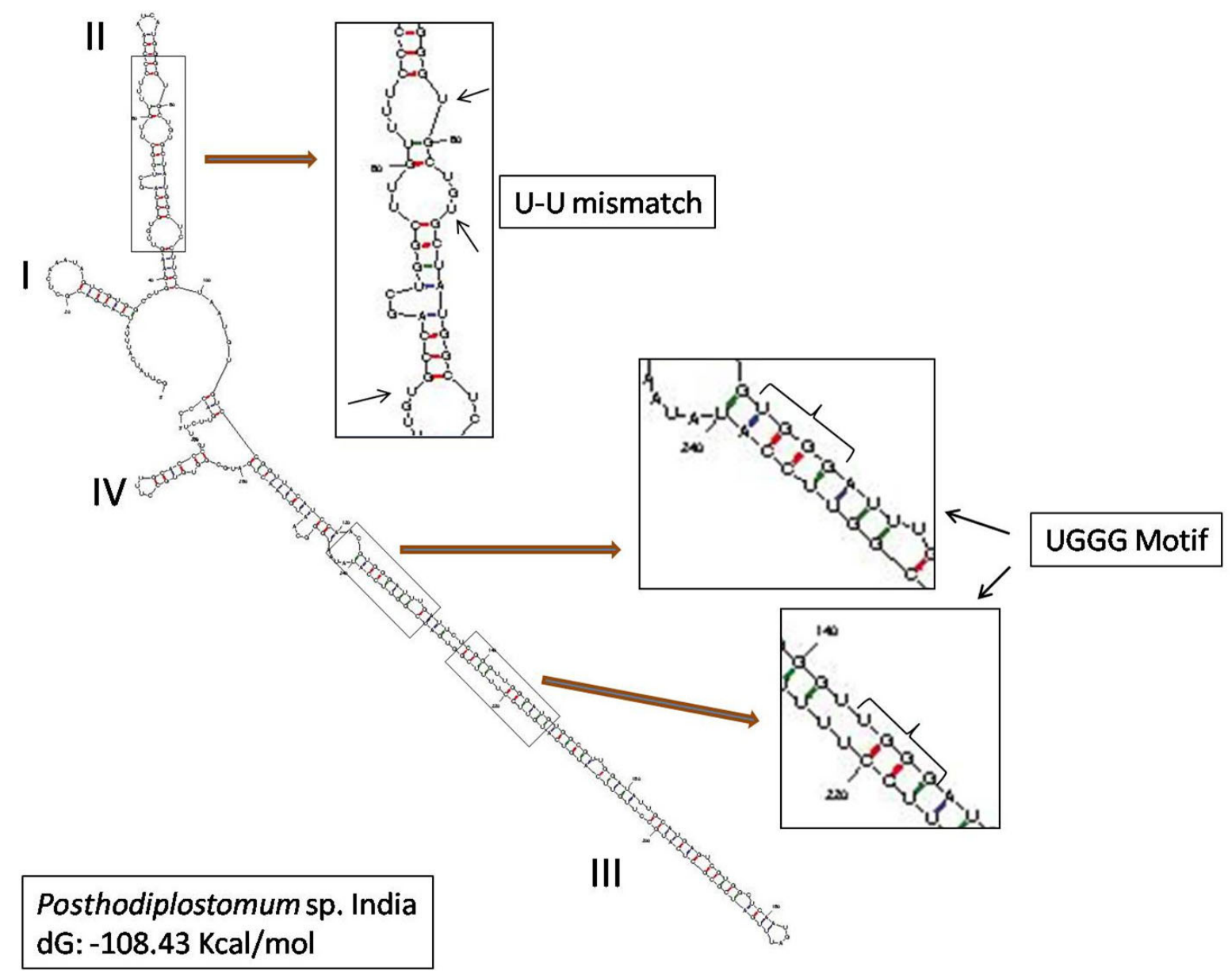

Fig. 4a. Inferred secondary structure of the ITS2 region; the motifs: U-U mismatch in helix II and UGGG in helix IV are shown 


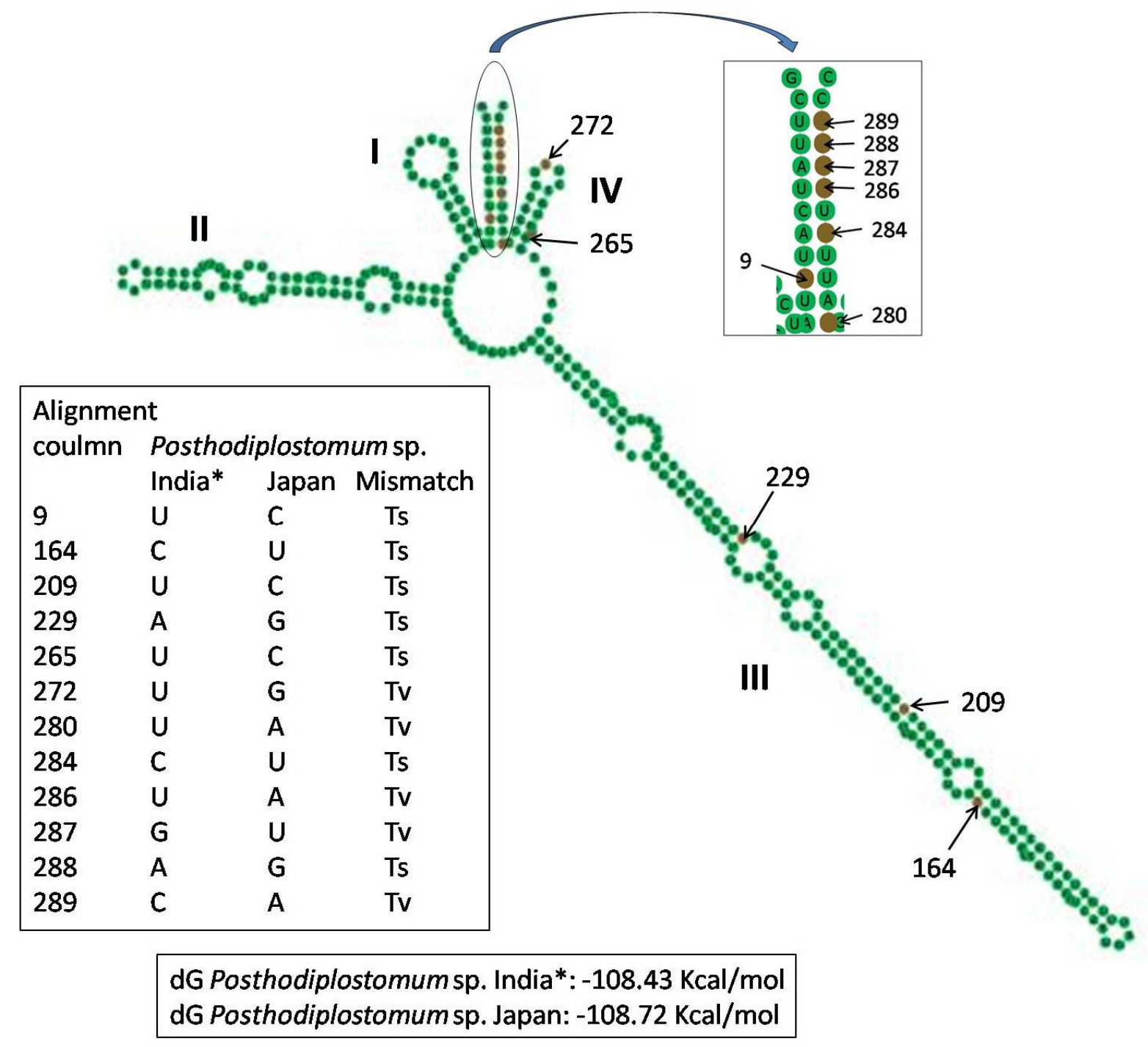

Fig. 4b. Consensus secondary structure of the ITS2 marker in the presently studied metacercaria and Posthodiplostomum sp. Japan isolate. U - Uracil, C - Cytosine, G - Guanine, Ts - Transition, Tv - Transversion. (‘*’ - query sequence)

model, showing twelve mismatches with seven transitions and five transversions at various positions in helix III, helix IV, and 3' and 5' open ends; helix I and II show complete conservedness in their sequences with no mismatches between them.

\section{Discussion}

In recent years DNA-based PCR amplification techniques have especially proven useful in quick and accurate identification of morphologically similar but genetically distinct species, and thus helped in resolving taxonomic issues involving various animal taxa including platyhelminth (McManus \& Bowles, 1996; Thompson et al., 2004; Olson \& Tkach, 2005). Nguyen et al. (2012) utilized both morphometric and molecular techniques to characterize a diplostomid metacercarial stage found infecting the muscle of Channa argus. In the present study, we tried to identify the metacercarial parasite of $C$. punctata by utilizing both morphological and molecular approaches.

The present form was found to belong to the family Diplostomidae Poirier, 1886 based on morphological criteria (Yamaguti, 1971; Niewiadomska, 2001). The present metacercaria possesses all morphological features typical of Posthodiplostomum genus (e.g. distinctly bipartite body, trybocytic organ disc-shaped with a median slit) and shows well-developed gonads and anlagen of some genital organs, but no melanin. From India, only five species of Posthodiplostomum have been reported till date; these are: P. cuticola (v Nordman, 1832) Dubois, 1936; P. botauri Vidyarthi, 1938; P. grayii (Verma, 1936) Dubois, 1938; P. mehtai Gupta and Mishra, 1974 and P. milvi Fotedar and Raina, 1965 from the avian (final) hosts (Yamaguti, 1971). The degree of development of the reproductive anlagen may be related to the host age and the time length of infection in the fish host (Graczyk, 1991; Niewiadomska \& Szymański, 1991). While metacercariae of $P$. podicipitis and other Posthodiplostomum species (occurring in the fish 
host Oryzias latipes) possess well-developed genital organs (Toyooka \& Okada, 1954), those of Posthodiplostomum sp. reported from muscle of Channa argus in Japan and $P$. cuticola from skin, fins and muscle of Phoxinus laevis have primordial form of genital organs (Dönges, 1964; Nguyen et al., 2012).

In phylogenetic analysis based on ribosomal or mitochondrial gene markers, our query sequences claded close to Posthodiplostomum sp. and members of the family Diplostomidae. Our results thus corroborate the morphologybased classification (Niewiadomska, 2001).

The ITS2 secondary structure is typically a four-helix model, which is common to almost all eukaryotic taxa (Coleman, 2003; Schultz et al., 2005) and is true for digenean trematodes as well (Morgan \& Blair, 1998). The conserved nature of ITS2 secondary structural core allows utility in inferring phylogenies at higher taxonomic levels, in addition to its role for low-level phylogenetic analyses on the species and genus levels (Schultz et al., 2006; Selig et al., 2008). The identical nature of the ITS2 secondary structure can be attributed to similarity in rRNA biogenesis among eukaryotes; its folding pattern plays an important role in processing of mature rRNA (Joseph et al., 1999) and structures are maintained during evolution through transitions/transversions, although mutations occur frequently (Coleman, 2007; Keller et al., 2010). The utility of ITS2 secondary structure for characterizing parasites has also been demonstrated (Shylla et al., 2011; Ghatani et al., 2012). A high degree of similarity in the ITS2 secondary structures of Posthodiplostomum sp. isolates corroborates the results of the primary sequence analysis in the present study.

On the basis of morphological study, supplemented with molecular characterization, the diplostomid metacercarial parasite studied herein is identified as belonging to the genus Posthodiplostomum Dubois, 1936.

\section{Acknowledgments}

The study was supported by Department of Information Technology (Ministry of Communication and Information Technology, Government of India under the "North-East Parasite Information and Analysis Centre (NEPIAC)" sanctioned to VT et al. [Sanction no.: DIT/R\&D/BIO/ $15(13) / 2008$ dated Sep. 29, 2008]. VDA is thankful to 'NEPIAC' for awarding 'Junior Research Fellowship', to University Grants Commission (UGC) for awarding 'Research Fellowship in Science for Meritorious Students' and to Council of Scientific \& Industrial Research (CSIR) for awarding 'Senior Research Fellowship'.

\section{References}

ATHOKPAM, V. D., TANDON, V. (2013): A survey of metacercarial infections in commonly edible fish and crab hosts prevailing in Manipur, Northeast India. J. Parasit. Dis., DOI 10.1007/s12639-013-0360-z

Avault, J. W., Smitherman, R. O. (1965): Experimental host specificity of Posthodiplostomum minimum. Exp. Parasitol., 17: 268 - 270. DOI: 10.1016/00144894(65)90069-X

Bowles, J., Blair, D., McManus, D. P. (1995): A molecular phylogeny of the human schistosomes. Mol. Phylogenet. Evol., 4: 103 - 109

Bowles, J., Hope, M., TiU, W.U., LiU, X., McManus, D. P. (1993): Nuclear and mitochondrial genetic markers highly conserved between Chinese and Philippine Schistosoma japonicum. Acta. Trop., 55: 217 - 229

CHUBB, J. C. (1977): Seasonal occurrence of helminthes in freshwater fishes. Part I. Monogenea. Adv. Parasitol., 15: $133-199$

Coleman, A. W. (2003): ITS2 is a double-edged tool for eukaryote evolutionary comparisons. Trends Genet., 19: 370 - 375. DOI: 10.1016/S0168-9525(03)00118-5

Coleman, A. W. (2007): Pan-eukaryote ITS2 homologies revealed by RNA secondary structure. Nucleic Acids Res., 35: 3322 - 3329. DOI: 10.1093/nar/gkm233

Colley, F. C., Olson, A. C. J. (1963): Posthodiplostomum minimum (Trematoda: Diplostomidae) in fishes of Lower Otay Reservoir, San Diego County, California. J. Parasitol., 49: 148

Criscione, C. D., Poulin, R., Blouin, M. S. (2005): Molecular ecology of parasites: elucidating ecological and microevolutionary processes. Mol. Ecol., 14: 2247 - 2257. DOI: 10.1111/j.1365-294X.2005.02587.x

Diez, B., Pedros-Alio, C., Massana, R. (2001): Study of genetic diversity of eukaryotic picoplankton in different oceanic regions by small-subunit rRNA gene cloning and sequencing. Appl. Environ. Microbiol., 67: 2932 - 2941. DOI: 10.1128/AEM.67.7.2932-2941.2001

DöngES, J. (1964): The life cycle of Posthodiplostomum cuticola (v. Nordmann, 1832) Dubois, 1936 (Trematoda, Diplostomatidae). Z. Parasitenkd., 24: 169 - 248

DöNGES, J. (1969): Entwicklungs- und lebensdauer von metacercariaen. Z. Parasitenkd., 31: $340-366$

Galazzo, D. E., Dayanandan, S., Marcogliese, D. J., MCLAUGHLIN, J. D. (2002): Molecular systematics of some North American species of Diplostomum (Digenea) based on rDNA-sequence data and comparisons with European congeners. Can. J. Zool., 30: 2207 - 2217. DOI: 10.1139/Z02-198

Ghatani, S., Shylla, J. A., Tandon, V., Chatterjee, A., RoY, B. (2012): Molecular characterization of pouched amphistome parasites (Trematoda: Gastrothylacidae) using ribosomal ITS2 sequence and secondary structures. $J$. Helminthol., 86: $117 \quad-\quad 124 . \quad$ DOI: 10.1017/S0022149X11000125

GRACZYK, T. (1991): Variability of metacercariae of Diplostomum spathaceum (Rudolphi, 1819). (Trematoda, Diplostomidae). Acta. Parasitol., 36: 135 - 139

HALL, T. A. (1999): BioEdit: a user-friendly biological sequence alignment editor and analysis program for Windows 95/98/NT. Nucleic Acids Symposium Series, 41: 95 - 98

HuelsenBeck, J. P., RonQuist, F. (2001): MRBAYES: Bayesian inference of phylogeny. Bioinformatics, 17: 754 - 755. DOI: 10.1093/bioinformatics/17.8.754 
IsHII, S. (1951): Diplostomiasis of crucian carp in Japan. Dbutsugaku zasshi, 27: 410 - 411 (in Japanese)

JALALI, B. (1998): The parasites and parasitic diseases of freshwater fishes of Iran. Iranian Fisheries Company Publications, pp: 563

Joseph, N., Krauskopf, E., Vera, M. I., Michot, B. (1999): Ribosomal internal transcribed spacer 2 (ITS2) exhibits a common core of secondary structure in vertebrates and yeast. Nucleic Acids Res., 27: 4533 - 4540. DOI: $10.1093 /$ nar/27.23.4533

KARIMIAN, E., GHORBANI, R., HAJIMORADLOU, A. (2013): First occurrence and intensity of Posthodiplostomum cuticola (Nordmann, 1832) (Digenea; Diplostomatidae) metacercariae in monkey goby (Neogobius pallasi Berg, 1916) in the Zarringol stream, Golestan Province, Iran. Global Veterinaria, 10 (5): 505 - 510. DOI: 10.5829/idosi.gv.2013.10.5.20413

Keller, A., Forster, F., Muller, T., DandeKar, T., Schultz, J., WOLF, M. (2010): Including RNA secondary structures improves accuracy and robustness in reconstruction of phylogenetic trees. Biol. Direct, 5: 4. DOI: 10.1186/1745-6150-5-4

Keller, A., Schleicher, T., Schultz, J., Müller, T., DANDEKAR, T., WOLF, M. (2009): 5.8S-28S rRNA interaction and HMM-based ITS2 annotation. Gene, 430: 50 - 57. DOI: 10.1016/j.gene.2008.10.012

KurochKin, Y. V., Biserova, L. I. (1996): The etiology and diagnostics of 'black-spot disease' in fish. Parazitologiya, 30: 117 - 125

LANE, R. L., MORRIS, J. E. (2000): Biology, prevention, and effects of common grubs (digenetic trematodes) in freshwater fish. Tech. Bull. Series (Iowa State Univ), 115: $1-6$

LEWIS, W. M., NicKuM, J. (1964): The effect of Posthodiplostomum minimum upon the body weight of the bluegill. Prog. Fish-Cult., 26(3): 121-123

LUCKY, Z. (1970): Pathological changes with posthodiplostomosis of fish fry. Acta. Vet. Brno., [Suppl]. 1: 51 - 66

Mcmanus, D. P., Bowles, J. (1996): Molecular genetics approaches to parasite identification: their value in diagnostic parasitology and systematics. Int. J. Parasitol., 26: 687-104. DOI: 10.1016/0020-7519(96)82612-9

Morgan, J. A. T., Blair, D. (1998): Trematode and monogenean rRNA ITS2 secondary structures support a fourdomain model. J. Mol. Evol., 47: 406 - 419

Nagasawa, K., AWAKURA, T., UrawA, S. (1989): A checklist and bibliography of parasites of freshwater fishes of Hokkaido. Sci. Rep. Hokkaido Fish Hatch, 44: 1 - 49

Nguyen, T. C., Li, Y-C., Makouloutou, P., Jimenez, L. A., SATO, H. (2012): Posthodiplostomum sp. metacercariae in the trunk muscle of Northern snakeheads (Channa argus) from the Fushinogawa River, Yamaguchi, Japan. $J$. Vet. Med. Sci., 74 (10): 1367 - 1372. DOI: 10.1292/jvms. 12-0025

NiEWIADOMSKA, K. (2001): Family Diplostomidae Poirier, 1886. In: GiBson, D. I., Jones, A., BrAY, R. A. (Eds) Keys to the Trematoda, Volume 1. London, CABI Publishing and The Natural History Museum, pp. 167 - 196
NiEWIAdOMSKA, K., LASKOWsKi, Z. (2002): Systematic relationships among six species of Diplostomum Nordmarm, 1832 (Digenea) based on morphological and molecular data. Acta. Parasitol., 47: 20 - 28

NiEWIADOMSKA, K., SZYMAŃSKI, S. (1991): Host-induced variability of Diplostomum paracaudum (Lies, 1959) metacercariae (Digenea). Acta. Parasitol. Pol., 36: 11 - 17

Nolan, M. J., CRIBB, T. H. (2005): The use and implications of ribosomal DNA sequencing for the discrimination of digenean species. Adv. Parasitol., 60: 102 - 163. DOI: 10.1016/S0065-308X(05)60002-4

Olson, P. D., TKACH, V. V. (2005): Advances and trends in the molecular systematics of the parasitic platyhelminthes. Adv. Parasitol., 60: 165 - 243. DOI: 10.1016/S0065-308X(05)60003-6

ONDRAČKOVÁ, M., JURAJdA, P., GELNAR, M. (2002): The distribution of Posthodiplostomum cuticola metacercariae in young-of-the-year cyprinid fishes. J. Fish Biol., 60: 1355-1357. DOI: 10.1111/j.1095-8649.2002.tb01731.x

ONDRAČKOVÁ, M., REICHARD, M., JURAJDA, P., GELNAR, M. (2004a): Seasonal dynamics of Posthodiplostomum cuticola (Digenea, Diplostomatidae) metacercariae and parasite-enhanced growth of juvenile host fish. Parasitol. Res., 93: 131 - 136. DOI: 10.1007/s00436-004-1123-7

OndraČKOVÁ, M., ŠIMKOVÁ, A., GElnAR, M., JuRAJdA, P. (2004b): Posthodiplostomum cuticola (Digenea: Diplostomatidae) in intermediate fish hosts: factors contributing to the parasite infection and prey selection by the definitive bird host. Parasitology, 129: $761-770$

ROLBIECKI, L. (2004): Distribution of Posthodiplostomum cuticola (Nordmann, 1832) (Digenea; Diplostomidae) metacercariae in cyprinids of the Vistula lagoon, Poland. Archives of Polish Fisheries, 12(1): 93 - 98

SCHÄPPERCLAUS, W. M. (1990): Fischkrankheiten. Academie Verlag, Berlin. 5. Auflage

Schultz, J., Maisel, S., Gerlach, D., Müller, T., Wolf, M. (2005): A common core of secondary structure of the internal transcribed spacer 2 (ITS2) throughout the Eukaryota. $R N A, 11$ : 361 - 364. DOI: 10.1261/rna.7204505 Schultz, J., Müller, T., Actziger, M., Seibel, P. N., DANDEKAR, T., WOLF, M. (2006): The internal transcribed spacer 2 database - a web server for (not only) low level phylogenetic analyses. Nucleic Acids Res., 34: 704 - 707. DOI: $10.1093 /$ nar/gkl129

Seibel, P. N., Müller, T., Dandekar, T., Schultz, J., WOLF, M. (2006): 4SALE - a tool for synchronous RNA sequence and secondary structure alignment and editing. BMC Bioinformatics, 7: 498. DOI: 10.1186/1471-2105-7498

Selig, C., Wolf, M., Müller, T., DandeKar, T., SchulTz, J. (2008): The ITS2 Database II: homology modelling RNA structure for molecular systematics. $\mathrm{Nu}$ cleic Acids Res., 36: D377 - D380. DOI: 10.1093/nar/gkm827

Shukhgalter, O., Chukalova, N. (2002): An investigation of "black spot" disease of bream (Abramis brama) from Curonian Lagoon, south-east Baltic Sea. Bull. Eur. Assoc. Fish. Pathol., 22: 218-221 
Shylla, J. A., Ghatani, S., Chatterjee, A., Tandon, V. (2011): Secondary structure analysis of ITS2 in the rDNA of three Indian paramphistomid species found in local livestock. Parasitol. Res., 108: 1027 - 1032. DOI: 10.1007/s00436-010-2148-8

SKRJABIN, K. I. (1964): Trematodes of animals and man: Essentials of trematodology, Vol. XVII, Israel Program for Scientific Translations, Jerusalem (translated in English by Birron, A. and Cole, Z. S.)

Sonin, M. D. (1986): Key to the trematode parasites of fish-eating birds in Palearctic Region, Nauka, Moscow Stanevičiūtė, G., Petkevičıūtė, R., Kiseliené, V. (1998): Karyological analysis of two species of genus Posthodiplostomum Dubois, 1936 (Trematoda: Diplostomidae) with remarks on the karyological evolution of Diplostomidae. Acta. Zool. Lit., 8(1): 41-47. DOI: 10.1080/13921657.1998.10541437

Tandon, V., Prasad, P. K., Chatterjee, A., Bhutia, P. T. (2007): Surface fine topography and PCR-based determination of metacercaria of Paragonimus sp. from edible crabs in Arunachal Pradesh, Northeast India. Parasitol. Res., 102: 21 - 28. DOI: 10.1007/s00436-007-0715-4

Thompson, R. C. A., Zarlenga, D. S., LA-Rosa, G., Pozio, E., Rosenthal, B., BAndi, C., Mortarino, M., Casiraghi, M., Genchi, C., Gasser, R. B., Hu, M., Chilton, N. B., Matthews, J. B., Hodgkinson, J. E. (2004): Advances in the diagnosis and systematics of parasites of veterinary importance: new and exciting prospects. In: GASser, R. B, ZARlenga, D. S. (Eds) Molecular systematics and diagnosis. Vet. Parasitol., 125: 69 - 72
TKach, V. V., Pawlowski, J., MariauX, J. (2000): Phylogenetic analysis of the suborder Plagiorchiata (Platyhelminthes, Digenea) based on partial lsrDNA sequences. Int. J. Parasitol., 30: 83 - 93. DOI: 10.1016/S00207519(99)00163-0

TOYOOKA, R., OKADA, K. (1954): Studies on the development of two diplostomatid metacercariae, found in Oryzias latipes, a freshwater fish. J Gakugei Tokushima Univ, 4: 55 $-64$

Vytautas, R., Èeslovas, B. (2009): Distribution, prevalence and intensity of roach (Rutilus rutilus (Linnaeus, 1758)) parasites in inland waters of Lithuania in 20052008. Acta. Zool. Lituanica, 19(2): 99 - 108. DOI: 10.2478/v10043-009-0017-4

YAMAGUTI, S. (1971): Synopsis of digenetic trematodes of vertebrates, Vol. I, II. Keigaku Publishing Co., Tokyo

ZhaO, G. H., LI, J., Mo, X. H., LI, X. Y., LIN, R. Q., ZOU, F. C., Weng, Y. B., Song H. Q., ZhU, X. Q. (2012): The second transcribed spacer rDNA sequence: an effective genetic marker for inter-species phylogenetic analysis of trematodes in the order Strigeata. Parasitol. Res., 111: 1467 - 1472. DOI: 10.1007/s00436-012-2981-Z

Zrnčić, S., Oraić, D., Mihaljević, Z., ĆAleta, M., ZANELlA, D., JeliĆ, D., JELIĆ, M. (2009): First observation of Posthodiplostomum cuticola (Nordmann, 1832) metacercariae in cypriniformes from Croatia. Helminthologia, 46: 112 - 116. DOI: 10.2478/s11687-009-0022-y

ZUKER, M. (2003): Mfold web server for nucleic acid folding and hybridization prediction. Nucleic Acids Res., 31: 3406 - 3415. DOI: 10.1093/nar/gkg595 